\title{
Plastic Mulches for the Production of Vegetable
}

Crops

William James Lament, Jr.

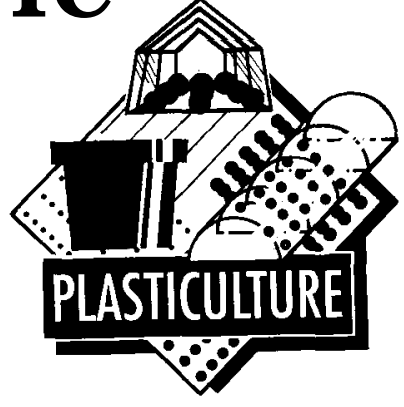

Additional index words. polyethylene, biodegradable, photodegradable, reflective, wavelengthselective

Summary. The development of polyethylene as a plastic film in 1938 and its subsequent introduction as a plastic mulch in the early 1950 s revolutionized the commercial production of selected vegetable crops. Throughout the succeeding years, research, extension, and industry personnel, together with growers, have documented the advantages of using plastic mulch as one component of a complete intensive vegetable production system. Although a variety of vegetables can be grown successfully using plastic mulches, muskmelons, honeydews, watermelons, squash, cucumbers, tomatoes, peppers, eggplant, okra, sweet corn, and cole crops have shown significant increases in earliness, total yield, and quality. Research continues on field evaluation of new formulations of degradable, wavelength-selective, and colored plastic mulches and on cropping systems to use best these specific improvements. The use of plastic mulches for the production of vegetable crops continues to increase throughout the United States and the world.

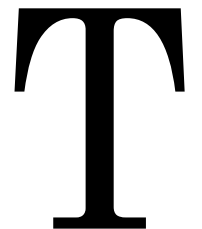

he cornerstone of the intensive production systems for vegetables, such as muskmelons, honeydews, watermelons, cucumbers, squash, peppers, eggplants, tomatoes, okra, sweet corn, and cole crops (in both single and multiple cropping situations), is plastic mulch. In addition, however, complete production packages include: drip irrigation, fertigation, containerized transplants, grain windbreaks, row covers, and a sound pest control program. Plastic mulches provide many positive advantages for the user, such as increased yields, earlier-maturing crops, higher-quality produce, insect management, and weed control. It also allows other components such as drip irrigation to achieve maximum efficiency. Today, more than 114 million pounds of plastic mulch is used annually in the United States (Ennis, 1987). 


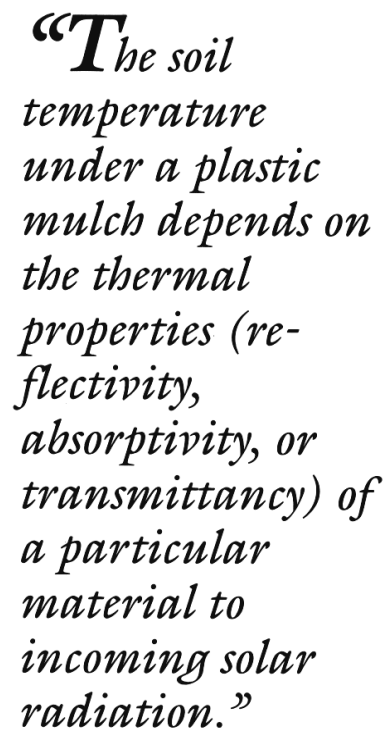

One of the first plastics produced on a commercial scale in 1939 was polyethylene (PE). The widespread use of PE in agriculture and, more specifically, as mulches, is due to its easy processing, excellent chemical resistance, high durability, flexibility, and freedom from odor and toxicity as compared to other polymers (Wright, 1968). The polyethylene resin comes to the manufacturing facility in the form of pellets, which are converted into flexible sheets of plastic film by either the "blown bubble" process or the "slot casting" method (Clarke, 1987). The main PE used in mulches is low-density PE, which is produced by the polymerization of ethylene under very high pressure. It has excellent tensile strength, which is required for mechanical application of the plastic mulch to the soil and to resist tearing when exposed to strong winds and foot traffic.

Various additives are incorporated into the plastic to modify or enhance specific properties of the finished product. These can include pigments for color, slip agents, antiblock agents, antioxidants, ultraviolet (UV) inhibitors/stabilizers, flame retardants, and photodegradable additives (Wright, 1968).

\section{Specifications}

Most of the plastic mulches used in the United States are $1.25-\mathrm{mi} 1(0.031-\mathrm{mm})$ thick and 48 inches $(122 \mathrm{~cm})$ wide and come on rolls 2400 feet $(731 \mathrm{~m})$ long. The width of the plastic mulch may vary from 36 to 60 inches (91 to $152 \mathrm{~cm}$ ), depending on the crop and cropping system. The plastic mulch will be either smooth or embossed with a diamond-shaped pattern that helps reduce expansion and contraction, which results in the loosening of the mulch from the raised bed.

Importance of color

The color of a mulch determines its energy-radiating behavior and its influence on the microclimate around the vegetable plant. Color determines the surface temperature of the mulch and the underlying soil temperatures. Much of the early pioneering research by Emmert (1957) on the use of plastic mulches for vegetable production was to define the impact differently colored mulches had on soil and air temperatures, moisture retention, and vegetable yields. Other researchers (Blackhurst, 1962; Schales and Sheldrake, 1962; Shadbolt, 1961; Takatori et al., 1964; Tukey and Schoff, 1963; Waggoner et al., 1960) worked mainly with three colors-black, clear, and white. These colors still predominate commercial vegetable production today, although white has been replaced largely by a co-extruded white-onblack.
The soil temperature under a plastic mulch depends on the thermal properties (reflectivity, absorptivity, or transmittancy) of a particular material to incoming solar radiation (Schales and Sheldrake, 1963). Black plastic mulch is an opaque black body absorber and radiator, absorbing most $W$, visible, and infrared wavelengths ofincoming solar radiation and re-radiating absorbed energy in the form of thermal radiation or longwavelength infrared radiation. Much of the solar energy absorbed by black plastic mulch is lost to the atmosphere through radiation and forced convection. The efficiency with which black mulch increases soil temperature can be improved by optimizing conditions for transferring heat from the mulch to the soil. Because thermal conductivity of the soil is high relative to that of air, a large proportion of the energy absorbed by black plastic can be transferred to the soil by conduction, if there is good contact between the plastic mulch and the soil surface. Soil temperatures under black plastic mulch during the daytime are generally $5 \mathrm{~F}(2.8 \mathrm{C})$ higher at a 2 -inch (5$\mathrm{cm})$ depth and $3 \mathrm{~F}(1.7 \mathrm{C})$ higher at a 4-inch $(10-\mathrm{cm})$ depth compared to that of bare soil. Black mulch is predominate in U.S. vegetable production systems.

By contrast, clear plastic mulch absorbs little solar radiation but transmits $85 \%$ to $95 \%$, with the relative transmission depending on the thickness and degree of opacity of the polyethylene. The lower surface of clear plastic mulch usually is covered with condensed water droplets. This water is transparent to incoming short-wave radiation, but is opaque to outgoing longwave infrared radiation, so that much of the heat lost to the atmosphere from a bare soil by infrared radiation is retained by clear plastic mulch. Thus, daytime soil temperatures under clear plastic mulch are generally 8 to $14 \mathrm{~F}$ ( 4.4 to $7.8 \mathrm{C}$ ) higher at a 2-inch $(5-\mathrm{cm})$ depth and 6 to $9 \mathrm{~F}$ (3.3 to $5.0 \mathrm{C})$ higher at a 4 -inch $(10-\mathrm{cm})$ depth compared to bare soil. Clear plastic mulches generally are used in the cooler regions of the United States.

White, white-on-black, or silver reflective mulches may result in a slight decrease in soil temperature-2F $(1.1 \mathrm{C})$ at a 1-inch $(2.5$ $\mathrm{cm})$ depth or $0.7 \mathrm{~F}(0.4 \mathrm{C})$ at a 4 -inch $(10-\mathrm{cm})$ depth compared to bare soil, because they reflect back into the plant canopy most of the incoming solar radiation. These mulches are used to establish crops like cauliflower or tomatoes in mid-summer, when soil temperatures are high and any reduction in soil temperatures is beneficial.

A new family of mulches includes wavelength-selective mulches, which selectively transmit radiation in some regions of the electromagnetic spectrum but not in others (Loy 
et al., 1989). These mulches absorb photosynthetically active radiation (PAR) and transmit solar infrared radiation, providing a compromise between black and clear mulches. The infrared-transmitting (IRT) mulches afford the weed control of black mulch, but are intermediate in terms of increasing soil temperature between black and clear mulch. The color of these mulches can be blue-green (IRT-76, AEP Industries Inc., Moonachie, N.J.; or Climagro, Leco Industries, Inc., Quebec, Canada) or brown (Polyon-Barkai, Poly West, Encinitas, Calif.). These mulches warm up the soil similar to clear mulch but without the accompanying weed problem.

Red, blue, orange-green, or yellow mulches reflect different radiation patterns into the plant canopy of a crop such as tomato, thereby affecting photosynthesis and/ or plant morphogenesis, and may increase early yields, as was the case with red mulch (Decoteau et al., 1988, 1989). The colors also can affect the behavior of certain insects. Yellow and, to a lesser degree, orange and green surfaces, attract the green peach aphid (Broadbent, 1948). Mulches with an aluminum or silver surface color have been shown to repel certain aphids and reduce incidence of aphid-borne viruses in summer squash (George and Kring, 1971; Lamont et al., 1990).

\section{Advantages of plastic mulches}

Earlier and higher overall yields. Raising the soil temperature promotes morerapid crop development and earlier yields (Clarkson and Frazier, 1957). Researchers have demonstrated earlier ( 7 to 14 days and up to 21 days) and increased yields (normally two to three times that of unmulched soils) depending on geographic location, soil type, plastic mulch used, and crop-sweet corn and eggplant (Pollack et al., 1969); tomatoes (Bhella, 1986); muskmelons (Schales and Sheldrake, 1.966); peppers (Stephenson and Bergman, 1963); cucumbers (Paterson, 1980); summer squash (Bhella and Kwolek, 1984); okra (Brown et al., 1986); and watermelons (Bhella, 1978).

Reduced evaporation. Because of the high degree of impermeability of plastic mulches to water vapor, soil water evaporative loss is reduced. The use of drip irrigation in conjunction with plastic mulch reduces moisture evaporation from the mulched soil and decreases irrigation requirements (Hanlon and Hochmuth, 1989). This has been related to water savings of $45 \%$ compared to overhead sprinkler systems (Clough et al., 1987; Jones et al., 1977).

Fewer weed problems. Black, white-onblack, reflective, and wavelength-selective mulches will reduce light penetration into the soil. Weeds generally cannot survive under the mulch. An exception is nutgrass, whose nut-like tubers provide enough energy for the seedling to puncture the mulch and emerge. With clear plastic mulch, a herbicide or fumigation is needed to prevent weed growth beneath it.

Reduced fertilizer leaching. Excess water runs off the impervious mulch. Fertilizer beneath the mulch is not lost by leaching (Locascio et al., 1985). The plastic mulch aids in retention of nutrients within the root zone, permitting more efficient nutrient use by the vegetable crop (Cannington et al., 1975).

Reduced soil compaction. Soil under the plastic mulch remains loose, friable, and wellaerated. Roots have access to adequate oxygen and microbial activity is enhanced (Hankin et al., 1982).

Root pruning eliminated. Except for the area between the mulched beds, cultivation is eliminated. Weed growth in these areas can be controlled by an approved herbicide.

Cleaner product. The edible product from a mulched crop is clean and less subject to rots, because soil is not splashed on the plants or fruit. This is accomplished by a raised bed that is firm and tapered away from the row center, and plastic mulch that is stretched tightly to encourage water runoff.

Gas exchange. Mulch film is nearly impervious to carbon dioxide released by roots or decomposition of organic matter in the soil, so it accumulates beneath the plastic mulch (Sheldrake, 1963; Baron and Gorske, 1981). Because the film does not allow the gas to penetrate, it has to escape through the holes punched for the plants. This creates a "chimney effect," resulting in higher levels of $\mathrm{CO}$, for the actively growing leaves near the transplant hole (Hopen, 1965).

Aids in fumigation and soil solarization. Mulches increase the effectiveness of soil fumigant chemicals. Because of the impervious nature of the plastic mulch, it acts as a barrier to gas escape and keeps gaseous fumigants in the soil (Scoville and Leaman, 1965). Plastic mulches, especially clear, are used in soil solarization to control soil pests (Stapleton, 1991).

Reduced drowning of crops. Water is shed from the row area by the tapered bed; excess water runs off the field, reducing drowning and other excess soil water stress.

Ability to double/triple crop. Once the first crop has been harvested, a second crop can be grown on the plastic mulch. This "intensive cropping" produces two or three crops from the annual expenses for plastic mulch and drip irrigation tubing. The second or third crop can be fertilized through the drip irrigation line (fertigation) using soluble fertilizers and a fertilizer injector (Clough et al., 1987; Marr and Lamont, 1992).
Cre use of drip irrigation in conjunction with plastic mulch reduces moisture evaporation from the mulched soil and decreases irrigation requirements.” 


\section{"Plastic mulches bave allowed for greater mechanization and efficiency in the production of selected pegetable crops since the late 1950s and will continue to provide a proven means of modifying the micro- environment around a vegetable crop."}

\section{Disadvantages of plastic mulches}

Removal and disposal. A major problem with plastic mulch is removal from the field after cropping (Stalland Bryan, 1981). Plastics have been disposed of routinely by burning, burial, or dumping in landfills. The growing environmental concerns over disposal of plastic mulches by burning and dumping in landfills already has led to restrictions in some regions (Ennis, 1987).

In the early 1960 s, photo- or biodegradable plastic was recognized as one solution to the disposal problem associated with plastic mulches. Work on biodegradable starch-based film (Otey and Westoff, 1980) and photodegradable polyolefin polymer and polyethylene copolymer films (Carnell, 1980; Ennis, 1987) has been underway since the 1960s; however, resulting mulches have been quite variable in their rate of degradation (Chu and Matthews, 1984; Wien, 1981).

Recently, newer photodegradable products (Optigro, Leco Industries, Inc., Quebec, Canada; Biolan, CT Films, Schaumburg, Ill.; and Plastigone, Miami, Fla.) have shown more-satisfactory degradation characteristics when tested in different regions of the country (Clough and Reed, 1989; Johnson, 1989; Kostewicz and Stall, 1989; Sanders et al., 1989; Wolfe, 1989).

Other options to the plastic mulch disposal problems are retrieval and recycling or incineration/energy reclamation for the BTUs locked inside the plastic mulch.

Greater initial cost. The use of plastic mulch will increase the cost ofproduction for a given crop. This is due to investment in some specialized equipment, including a bed press, mulch layer, and mulch transplanter or plug-mix seeder. These costs must be offset by increased income from earlier harvests, higher yields, and better-quality fruit to create an economic advantage for the use of plastic mulch.

Plastic mulches have allowed for greater mechanization and efficiency in the production of selected vegetable crops since the late 1950s and will continue to provide a proven means of modifying the micro-environment around a vegetable crop.

\section{Literature Cited}

Baron, J.J. and S.F. Gorske. 1981. Soil carbon dioxide levels as affected by plastic mulches. Proc. 16th Natl. Agr. Plastics Congr. p. 149-155.

Bhella, H.S. 1978. Watermelon growth, yield and nutrition as influenced by plastic mulch and trickle irrigation. Proc. 19th Nan. Agr. Plastics Congr. p. 295-301.

Bhella, H.S. and W.F. Kwolek. 1984. The effects of trickle irrigation and plastic mulch on zucchini. HortScience 19:410-411.
Bhella, H.S. 1986. Effect of plastic mulch and trickle irrigation on tomato growth, yield and nutrition. Proc. 19th Nan. Agr. Plastics Congr. p. $80-86$.

Blackhurst, H.T. 1962. Commercial use of black plastic mulch. Proc. Nan. Hort. Plastics Conf. p. 27.

Broadbent, L. 1948. Aphid migration and efficiency of the trapping method. Ann. Applied Biol. 35:379-394.

Brown, J.E., G.A. Lewis, and H.M. Bryce. 1986. Influence of black plastic mulch and row covers on the growth and performance of okra intercropped with turnip greens. Proc. 19th Natl. Agr. Plastics Congr. p. 148-157.

Cannington, F., R.B. Duggings, and R.G. Roan. 1975. Florida vegetable production using plastic film mulch with drip irrigation. Proc. 12th Natl. Agr. Plastics Congr. p. 11-15.

Carnell, D. 1980. Photodegradable mulch eliminates costly removal steps. Proc. 15th Natl. Agr. Plastics Congr. p. 94-96.

Chu, C.-c. and D.L. Matthews. 1984. Photodegradable plastic mulch in central New York. HortScience 19:497-498.

Clarke, A.D. 1987. Some plastic industry development; their impact on plastic films for agricultural application. Plasticulture 74:15-26.

Clarkson, V.A. and W.A. Frazier. 1957. Effect of paper and polyethylene mulches and plastic caps on cantaloupe yields and earliness. Proc. Amer. Soc. Hort. Sci. 69:400-404.

Clough, G.H., S.J. Locascio, and S.M. Olson. 1987. Continuous use of polyethylene mulched beds with overhead or drip irrigation for successive vegetable production. Proc. 20th Natl. Agr. Plastics Congr. p. 57-61.

Clough, G.H. and G.L. Reed. 1989. Durability and efficiency of photodegradable mulches in dripirrigated vegetable production systems. Proc. 21st Natl. Agr. Plastics Congr. p. 42-45.

Decoteau, D.R., M.J. Kasperbauer, D.D. Daniel, and P.G. Hunt. 1988. Plastic mulch color effects on reflected light and tomato plant growth. Scientia Hort. 34:169-175.

Decoteau, D.R., M.J. Kasperbauer, and P.G. Hunt. 1989. Mulch surface color affects yield of freshmarket tomatoes. J. Amer. Soc. Hort. Sci. 114:216219.

Emmert, E.M. 1957. Black polyethylene for mulching vegetables. Proc. Amer. Soc. Hort. Sci. 69:464467.

Ennis, R.S. 1987. Plastigone ${ }^{\mathrm{TM}}$ a new, time-controlled, photodegradable, plastic mulch film. Proc. 20th Natl. Agr. Plastics Congr. p. 83-90.

George, W.L., Jr., and J.B. Kring. 1971. Virus protection of late season summer squash with aluminum mulch. Connecticut Agr. Expt. Sta. Bul. 239. 
Hankin, L., D.E. Hill, and G.R. Stephens. 1982. Effects of mulches on bacterial population and enzyme activity in soil and vegetable yields. Plant \& Soil Sci. 64:193-201.

Hanlon, E.A. and G.J. Hochmuth. 1989. Fertilizer recommendations for vegetables grown in polyethylene mulch. Proc. 21st Natl. Agr. Plastics Congr. p. 165-171.

Hopen, H.J. 1965. Effects of black and transparent polyethylene mulches on soil temperature, sweet corn growth and maturity in a cool growing season: Proc. Amer. Soc. Hort. Sci: 86:415-423.

Johnson, H. 1989. Plastigone photodegradable film performance in California. Proc. 21st Natl. Agr. Plastics. Congr. p. 1-6.

Jones, T.L., U.S. Jones, and D.O. Ezell. 1977. Effect of nitrogen and plastic mulch on properties of troup loamy sand and yield of Walter tomatoes. J. Amer. Soc. Hort. Sci. 102:273-275.

Kostewicz, S.R. and W.M. Stall. 1989. Degradable mulches with watermelons under north Florida conditions. Proc. 21st Natl. Agr. Plastics Congr. p. $17-21$.

Lament, W.J., K.A. Sorenson, and C.W. Averre. 1990. Painting aluminum strips on black plastic mulch reduces mosaic symptoms on summer squash. HortScience 25:1305.

Locascio, S.J., J.G.A. Fiskell, D.A. Graetz, and R.D. Hawk. 1985. Nitrogen accumulation by peppers as influenced by mulch and time of fertilizer application. J. Amer. Soc. Hort. Sci. 110:325328.

Loy, B.,J. Lindstrom, S. Gordon, D. Rudd, and O. Wells. 1989. Theory and development of wavelength selective mulches. Proc. 21st Natl. Agr. Plastics Congr. p. 193-197.

Marr, C.W. and W.J. Lamont. 1992. Profits, profits, profits-Three good reasons to try triple cropping. Amer. Veg. Grower 40:18,20.

Otey, F.H. and R.P. Westoff: 1980. Biodegradable starch-based plastic films for agricultural application. Proc. 15th Natl. Agr. Plastics Congr. p. 9093.

Paterson, J.W. 1980. Fertilizing mulched and unmulched cucumbers. Proc. 15th Natl. Agr. Plastics Congr. p. 97-99.

Pollack, G.L., N.J. Smith, and J.C. Cialone. 1969. Summary of crop response to various agricultural film mulches. Proc. 9th Natl. Agr. Plastics Conf. p. $17-25$.
Sanders, D.C., C.A. Prince, and P.P. David. 1989. Photodegradable plastics in North Carolina. Proc. 21st Natl. Agr. Plastics Congr. p. 11-16.

Schales, F.D. and R. Sheldrake. 1962. Mulch-soilplant relationships. Proc. Natl. Hort. Plastics Conf. p. 23.

Schales, F.D. and R. Sheldrake. 1963. Mulch effects on soil conditions and tomato plant response. Proc. 4th Natl. Agr. Plastics Conf. p. 78-90.

Schales, F.D. and R. Sheldrake Jr. 1966. Mulch effects on soil conditions and muskmelon response. Proc. Amer. Soc. Hort. Sci. 88:425-430.

Scoville, R.H. and D. Leaman. 1965. Polyethylene uses in soil fumigation. Proc. 6th Natl. Agr. Plastics Conf. p. 98-99.

Shadbolt, A.C. 1961. Soil and air temperature patterns under continuous plastic covers and mulches. Proc. Natl. Hort. Plastics Conf. p. 19.

Sheldrake, R. 1963. Carbon dioxide levels in the microclimate influences insect control and yield in vegetables. J. Amer. Soc. Hort. Sci. 104:759-962.

Stall, W.M. and H.H. Bryan. 1981. Removal and disposal of plastic mulch in Florida. Proc. 16th Natl. Agr. Plastic Congr. p. 133-141.

Stapleton, J.J. 1991. Use of soil solarization for the control of soil pests. Proc. 23rd Natl. Agr. Plastics Congr. p. 266-271.

Stephenson, K.Q. and E.L. Bergman. 1963. Some mechanical and cultural developments on the Penn State transplanter mulcher. Proc. 4th Natl. Agr. Plastics Conf. p. 58-64.

Takatori, F.H., L.F. Lippert, and F.L. Whiting. 1964. The effect of petroleum mulch and polyethylene films on soil temperature and plant growth. Proc. Amer. Soc. Hort. Sci. 84:532-540.

Tukey, R.B. and E.L. Schoff. 1963. Influence of different mulching materials on the soil environment. Proc. Amer. Soc. Hort. Sci. 82:68-76.

Waggoner, P.E., P.M. Miller, and H.C. DeRoo. 1960. Plastic mulching, principles and benefits. Connecticut Agr. Expt. Sta. Bul. 634.

Wien, H.C. 1981. Are photodegradable mulches practical for New York State growers? Proc. 16th Natl. Agr. Plastics Congr. p. 103-110.

Wolfe, D.W. 1989. Effects of environment or degradation rates of photodegradable plastic mulches. Proc. 21st Natl. Agr. Plastics Congr. p. 53-59.

Wright, J.C. 1968. Production of polyethylene film. Proc. 8th Natl. Agr. Plastics Conf. p. 72-79. 